\title{
Pengaruh Kompensasi Terhadap Kinerja Karyawan Pada Perusahaan Warunk Bendito Manado
}

\author{
Nirvana Monika Sangkaen \\ Wehelmina Rumawas \\ Sandra Asaloei \\ Jurusan Ilmu Administrasi, Program Studi Administrasi Bisnis \\ Fakultas Ilmu Sosial dan Politik Universitas Sam Ratulangi \\ E-mail: nirvanasangkaen@yahoo.com
}

\begin{abstract}
This study aims to determine the effect of compensation on employee performance. With the problem of compensation for the performance of employees at the Warunk Bendito Manado company. The sample taken was 34 people from a total of 34 employees in the company. In this study used a type of quantitative research. Technique data collection uses questionnaires to respondents, making observations and interviews. The technique used in data analysis is to use simple regression statistics with SPSS version 22.00 to test the significance of the relationship between variables and to measure the magnitude of the effect that occurs on compensation variables and employee performance variables. From the results of t test and correlation, it can be seen that the results of $t_{\text {value }}<t_{\text {table }}$ have a negative influence. The results of the $R$ square correlation value have a weak correlation. Based on the results of calculations from the study it can be seen that the compensation variable has a negative effect on employee performance variables.
\end{abstract}

Keywords: Compensation, Employee Performance

\section{Pendahuluan}

Sumber daya manusia merupakan aset paling penting yang harus dimiliki oleh organisasi dan harus diperhatikan dalam manajemen, karena mereka inilah yang bekerja membuat tujuan, mengadakan inovasi dan mencapai tujuan organisasi. Dalam suatu organisasi yang menjadi peran utama adalah personalianya untuk dapat menggerakan pekerjaan yang bekerja dengan berdasarkan kuantitas dan kualitas. Jika sebaliknya sumber daya manusia atau personalia di dalamnya tidak dapat bekerja secara efektif dan efisien maka perusahaan tidak dapat mencapai tujuan yakni memperoleh omset yang maksimal. Kompensasi dapat diartikan sebagai sesuatu yang diterima karyawan sebagai balas jasa perusahaan terhadap kinerja mereka. Kompensasi adalah bentuk balas jasa baik berupa uang, barang ataupun kenikmatan yang diberikan oleh perusahaan kepada karyawan atas kinerja yang disumbangkan kepada perusahaan. Salah satu cara terbaik untuk meningkatkan kinerja karyawan adalah dengan menghubungkan kompensasi dengan perkembangan karyawan. Jika program kompensasi dirasakan 
kompetitif oleh karyawan, maka perusahaan akan lebih muda untuk menarik karyawan yang potensial, mempertahankannya dan memotivasi karyawan agar lebih meningkatkan kinerjanya, sehingga produktivitas meningkat dan perusahaan mampu menghasilkan jasa yang terbaik. Hasibuan (2014) kompensasi adalah semua pendapatan yang berbentuk uang, barang langsung atau tidak langsung yang diterima karyawan sebagai imbalan atas jasa yang diberikan kepada perusahaan.Berdasarkan latar belakang yang telah dikemukakan terlebih dahulu, maka permasalahan pokok dalam penelitian ini dapat dirumuskan sebagai berikut: “Apakah terdapat pengaruh kompensasi terhadap kinerja karyawan pada Perusahaan Warunk Bendito Manado". Sedangkan tujuan penelitian yang ingin diperoleh pada penelitian ini adalah: Untuk Mengetahui Sejauh Mana Pengaruh Kompensasi (Finansial) Terhadap Kinerja Karyawan Pada Perusahaan Warunk Bendito Manado.

\section{Kompensasi}

Kompensasi adalah sesuatu yang diterima oleh para karyawan sebagai balas jasa atas kinerja yang diterapkan dalam suatu perusahaan.Kompensasi merupakan kontribusi penting bagi perusahaan terhadap karyawan untuk dapat mempertahankan dan meningkatkan kualitas kerja karyawan. Menurut Hasibuan (2013) tujuan kompensasi antara lain:a).
Ikatan kerja sama; b). Kepuasan kerja; c). Pengadaan efektif; d). Motivasi; e). Stabilitas karyawan; f). Disiplin; g). Pengaruh serikat buruh; h). Pengaruh pemerintah.Jadi secara umum kompensasi bertujuan untuk menarik karyawan dalam jumlah dan kualitas yang diinginkan, mendorong agar lebih berprestasi, serta dapat mempertahankan karyawan.Adapun faktor-faktor yang mempengaruhi kompensasi yang dikemukakan oleh Hasibuan (2000) antara lain: a). Penawaran dan Permintaan Tenaga Kerja; b). Kemampuan Untuk Membayar; c). Organisasi Buruh.d. Produktivitas; e). Pemerintah.f. Biaya Hidup; g). Posisi Jabatan Karyawan.h. Pendidikan dan Pengalaman Kerja; i). Kondisi Perekonomian Nasional; j). Jenis dan Sifat Pekerjaan.

\section{Kinerja Karyawan}

Kinerja merupakan suatu kemampuan yang dilakukan oleh individu atau seseorang karyawan dalam kegiatan dimana dalam pemberian tanggung jawab baik individu organisasi maupun perusahaan agar tercapainya tujuan yang ditentukan. Menurut Amstrong dan Baron (2007) kinerja merupakan hasil pekerjaan yang mempunyai hubungan kuat dengan tujuan strategi organisasi, kepuasan konsumen dan memberikan kontribusi ekonomi. Kinerja karyawan terkait dengan apa yang diharapkan dari hasil kerja seseorang. 
Untuk mewujudkan harapan tersebut diperlukan upaya dalam pencapaiannya. Salah satu teori yang dapat digunakan untuk meneropong kinerja karyawan adalah teori harapan dari Vroom yang menyatakan motivasi bergantung pada harapan-harapan para individu berkenaan dengan kemampuan mereka untuk mengerjakan tugas-tugas dan menerima penghargaanpenghargaan yang diinginkan (Daft 2007).

$$
\text { Pengertian kinerja menurut }
$$

Marwansyah (2014) mendefinisikan kinerja sebagai pencapaian atau prestasi seseorang berkenan dengan tugas-tugas yang dibebankan kepadannya, kinerja dapat pula dipandang sebagai perpaduan dari hasil kerja (apa yang harus dicapai oleh seseorang) dan kompetensi (bagaimana seseorang mencapainya).

Kinerja pada dasarnya adalah apa yang dilakukan oleh karyawan. Menurut Mangkunegara (2000) kinerja (prestasi kerja) adalah hasil kerja secara kualitas dan kuantitas yang dicapai oleh seseorang karyawan dalam melaksanakan tugasnya sesuai dengan tanggung jawab yang diberikan kepadanya. Kinerja merupkan hal yang sangat penting dalam suatu perusahaan untuk mencapai tujuannya. Kinerja dapat berjalan baik apabila karyawan mendapatkan gaji sesuai harapan, mendapatkan pelatihan dan pengembangan, lingkungan kerja yang kondusif, mendapatkan perlakuan yang sama, penjabatan karyawan sesuai keahliannya serta mendapatkan bantuan perencanaan karir, serta terdapat umpan balik dari perusahaan. Menurut Mangkunegara (2001) bahwa karakteristik orang yang mempunyai kinerja tinggi adalah sebagai berikut: a) Memiliki tanggung jawab pribadi yang tinggi; b) Berani mengambil dan menanggung resiko yang dihadapi; c) Memiliki tujuan yang realistis; d) Memiliki rencana kerja yang menyeluruh dan berjuang untuk merealisasi tujuannya; e) Memanfaatkan umpan balik (feed back) yang konkrit dalam seluruh kegiatan kerja yang dilakukannya; f) Mencari kesempatan untuk merealisasikan rencana yang telah diprogramkan.

Berdasarkan definisi di atas, kinerja karyawan dapat meningkat jika seseorang dapat melaksanakan tugas-tugas yang dibebankan dengan penuh tanggung jawab sehingga dapat mencapai hasil yang diinginkan semua pihak. Selain itu kinerja juga dapat dipengaruhi oleh tingkat pendidikan, kompensaasi, dan pengalaman bekerja karyawan.

Menurut Payaman J Simanjuntak (2005) menyatakan bahwa faktor-faktor yang mempengaruhi kinerja sebagai berikut: a) Faktor Individu: Kemampuan dan ketrampilan melakukan kerja. Kompetensi seseorang dipengaruhi oleh beberapa faktor yang dapat dikelompokan dalam dua golongan, yaitu kemampuan dan keterampilan kerja serta motivasi dan etos kerja; b). Faktor Organisasi. Dalam 
melaksanakan tugasnya, pegawai memerlukan dukungan organisasi tempat ia bekerja. Dukungan tersebut adalah dalam bentuk pengorganisasian, penyediaan sarana dan prasarana kerja, kenyamanan lingkungan kerja, serta kondisi dan syarat kerja; c). Faktor Manajemen. Kinerja perusahaan dan kinerja setiap orang juga sangat tergantung pada kemampuan manajerial para manajemen atau pimpinan, baik dengan membangun sistem kerja dan hubungan industrial yang aman dan harmonis, maupun dengan mengembangkan kompetensi pekerja, demikan juga dengan menumbuhkan motivasi seluruh karyawan untuk bekerja secara optimal.

Pengukuran kinerja adalah suatu proses organisasi dalam penilaian kerja karyawan. Tujuan ini dilakukan dengan penilaian kinerja secara umum adalah untuk memberikan feedback kepada pegawai dalam upaya memperbaiki tampilan kerja dan upaya meningkatkan kinerja organisasi, dan secara khusus dilakukan dalam kaitannya dengan berbagai kebijaksanaan terhadap pegawai untuk tujuan promosi, kenaikan gaji, pendidikan dan latihan.Menurut Hasibuan (2001) mengemukakan bahwa hampir seluru cara pengukuran kinerja mempertimbangkan kuantitas, kualitas, dan ketetapan waktu: a). Kuantitas, melibatkan keluaran atau output dari proses atau pelaksanaan kegiatan. Hal ini berkaitan dengan jumlah keluaran yang dihasilkan; b). Kualitas, keluaran yang mencerminkan pengukuran "tingkat kepuasan" yaitu seberapa baik penyelesaian, hal ini berkaitan bentuk keluaran; c). Ketetapan waktu, merupakan jenis khusus dari pengukuran kuantitatif yang menentukan ketepatan waktu penyelesaian suatu kegiatan.

\section{Hubungan Kompensasi dengan Kinerja Karyawan}

Hubungan antara kompensasi dengan kinerja karyawan sangat erat sekali, yaitu hubungan sebab-akibat (causally related). Oleh karena itu menurut Spencer and Spencer (1993) dalam Moeheriono (2010) hubungan antara kompensasi karyawan dengan kinerja adalah sangat erat dan penting sekali, relevansinya ada dan kuat, bahkan karyawan apabila ingin meningkatkan kinerja, seharusnya memiliki kompetensi yang sesuai dengan tugas pekerjaannya.Kompensasi dalam hal ini sebagai acuan untuk mendorong motivasi kerja karyawan yang lebih baik, jika kompensasi yang diberikan mereka rasakan tepat adanya maka akan timbul dari diri karyawan untuk bekerja lebih baik. Dengan demikian kompensasi dapat mempengaruhi peningkatan kinerja karyawan. Sebaliknya, jika oleh perusahaan. Jika karyawan merasa diperhatikan umumnya karyawan akan berusaha untuk melakukan yang terbaik bagi perusahaan, sehingga peningkatan kerja mereka yang terakumulasi akan 
meningkatkan kinerja dan tujuan perusahaan juga akan dapat dicapai. Dari hasil uraian tersebut dapat kita lihat bahwa pemberian kompensasi kepada karyawan sangat erat hubungannya terhadap harapan akan peningkatan kinerja dalam suatu perusahaan atau sebuah organisasi.

\section{Metode Peneletian}

Jenis Penelitian ini merupakan jenis penelitian asosiatif kuantitatif. Menurut Sugiyono (2003) metode kuantitatif adalah penelitian dengan memperoleh data yang berbentuk angka atau data kualitatif yang diangkakan. Menurut Sugiyono (2008) mengemukakan bahwa populasi adalah wilayah generalisasi yang terdiri atas objek / subjek, yang mempunyai kualitas dan karakteristik tertentu yang ditetapkan oleh peneliti untuk dipelajari dan kemudian ditarik kesimpulannya. Yang menjadi populasi dalam penelitian ini adalah Karyawan Perusahaan Warunk Bendito Manado. Menurut Sugiyono (2008) adalah bagian dari jumlah dan karakteristik yang dimiliki oleh populasi tersebut. Sampel dalam penelitian ini adalah semua karyawan yang bekerja di Perusahaan Warunk Bendito, sampel yang digunakan sebanyak 34 orang.Yang menjadi Lokasi dalam penelitian ini adalah Perusahaan Warunk Bendito Manado. Sedangkan sumber data adalah Data primer adalah data yang diperoleh penulis melalui observasi atau pengamatan langsung dari perusahaan, baik itu melalui observasi, kuesioner dan wawancara secara langsung dengan atasan dan karyawan perusahaan sesuai dengan kebutuhan dalam penelitian ini. Dalam penelitian ini penulis mengumpulkan data yang diperlukan dengan cara melakukan pengamatan langsung pada perusahaan yang bersangkutan, baik melalui observasi, penyebaran kuesioner kepada para karyawan, dan wawancara. a). Observasi adalah teknik pengumpulan data dengan cara melakukan pengamatan langsung pada obyek yang diteliti sehingga diperoleh gambaran yang jelas mengenai masalah yang dihadapi; b). Kuesioner adalah pengumpulan data dengan cara menyebarkan daftar pertanyaan kepada responden yang dijadikan sebagai sampel penelitian; c). Wawancara adalah pengumpulan data dengan cara melakukan tanya jawab secara langsung dengan pihakpihak yang bersangkutan guna mendapatkan data dan keterangan yang menunjang analisis dalam penelitian.

Dalam penelitian ini, metode analisis yang digunakan untuk mengetahui pengaruh kompensasi terhadap kinerja karyawan adalah dengan menggunakan analisis regresi sederhana. Dengan menggunakan analisis regresi sederhana, hubungan antara variabel bersifat linier (garis lurus), dimana perubahan pada variabel $\mathrm{X}$ akan diikuti oleh perubahan pada variabel Y secara tetap. 


\section{Hasil Penelitian}

Berdasarkan hasil penelitian yang merupakan hasil analisi data yang diperoleh dari Perusahaan Warunk Bendito Manado, dimana yang dijadikan responden adalah berjumlah 34 karyawan. Dengan distribusi usia 17 - 25 tahun memiliki 29 responden lebih banyak, usia 26 - 30 tahun 4 responden lebih banyak dan pada usia lebih dari 31 tahun 1 responden. Jenis kelamin dari responden adalah dominan laki-laki 18 responden dan responden Perempuan 16 responden. Tingkat pendidikan terakhir responden S1 hanya 2 responden, SMK ada 14 responden dan SMA ada 18 responden lebih banyak. Masa kerja responden 5 bulan kebawah ada 10 responden, 5 bulan sampai 1 tahun ada 12 responden lebih banyak, 1 tahun sampai 2 tahun ada 7 responden dan 2 tahun ke atas ada 5 responden.

Berdasarkan hasil perhitungan program komputer SPSS versi 22.00 diperoleh hasil sebagai berikut: $\mathrm{Y}=34.495$ - 0.146X + e Berdasarkan persamaan regresi di atas, maka interpretasi dari koefisien masing-masing variabel sebagai berikut: 1). Konstanta sebesar 34.495 menyatakan bahwa jika variabel kompensasi (X) dianggap konstan, maka kinerja karyawan pada Perusahaan Warunk Bendito Manado akan positif; 2). -0.146 koefisiensi regresi (kompensasi) sebesar 0.146 yang berarti memiliki pengaruh negatif terhadap kinerja karyawan.
Untuk hasil dari hipotesis dengan menggunakan uji t berdasarkan alat bantu SPSS yaitu: a) Level of significant 0,05 Nilai t tabel: $\mathrm{t} \alpha / 2$; (n-k-1) t 0,025;34-1-1: 2.037 Ho diterima apabila $t_{\text {hitung }}<t_{\text {tabel }}$ atau $1.243<2.037$ Ho ditolak apabila $t_{\text {hitung }}>$ $t_{\text {tabel }}$ atau $-t_{\text {hitung }}>-t_{\text {tabel }}$ Nilai $t$ hitung: Dari hasil perhitungan melalui SPPS versi 22.00 dapat diperoleh $t_{\text {hitung }}$ sebesar -1.243 Kesimpulan: Dari perhitungan tersebut diperoleh hasil dari $t_{\text {hitung }}-1.243<\mathrm{t}_{\text {tabel }}$ 2.037, maka Ho diterima sehingga ada pengaruh negatif kompensasi terhadap kinerja karyawan.

\section{Pembahasan}

Berdasarkan hasil penelitian dengan menggunakan alat bantu software SPSS versi 22.00 menunjukan bahwa adanya pengaruh negatif signifikan terhadap variabel kompensasi terhadap vaiabel kinerja karyawan pada Perusahaan Warunk Bendito Manado.

Dari hasil penelitian diatas menunjukan bahwa kompensasi berpengaruh negatif terhadap kinerja karena adanya ketidak puasan karyawan dalam menerima kompensasi yang diberikan oleh perusahaan. Dilihat dari hasil penelitian diatas menunjukan juga bahwa kinerja karyawan sudah ada pada standar kinerja yang perusahaan butuhkan, namun dengan adanya pengeluhan dari karyawan dikarenakan kompensasi yang diberikan belum sesuai dengan harapan 
para karyawan yang ada di Perusahaan Warunk Bendito Manado.Dengan tidak adanya keseimbangan antara kompensasi terhadap kinerja dan kinerja terhadap kompensasi maka akan kurangnyakesejahteraan perusahaan terutama karyawan yang ada. Dan sebaliknya apabila kompensasi yang diberikan perusahaan kepada karyawan sudah sesuai dengan keinginan karyawan maka kinerja yang akan diberikan karyawan akan lebih meningkat dan akan mengurangi pengeluhan yang terjadi. Dalam penelitian ini peneliti hanya melakukan tentang penelitian kompensasi dan kinerja karyawan, sehingga dalam penelitian ini hanya dapat memberikan informasi seputar pengaruh dari kompensasi tersebut terhadap kinerja karyawan, dan penelitian yang dilakukan ini hanya memilih pada satu perusahaan kuliner saja.Berdasarkan hasil yang diperoleh persamaan regresi di atas, maka interpretasi dari koefisien masing-masing variabel sebagai berikut: a). Menyatakan bahwa jika variabel kompensasi (X) dianggap konstan, maka kinerja karyawan pada Perusahaan Warunk Bendito Manado akan positif; b). Koefisiensi regresi (kompensasi) memiliki pengaruh negatif terhadap kinerja karyawan. Dari hasil perhitungan Uji t yaitu memperoleh hasil Uji $\mathrm{t}$ berkaitan dengan kompensasi (X) terhadap kinerja karyawan (Y). Dengan demikian sesuai dengan hasil penelitian terdahulu oleh (Ischevell, dkk.2016) ternyata tidak memiliki kesamaan dengan hasil penelitian di atas. Begitu juga dengan hasil penelitian terdahulu oleh (Kenelak, dkk.2016) tidak ada kesamaan antara hasil penelitian di atas. Dan hasil penelitian terdahulu oleh (Wehelmina Rumawas 2015) ternyata juga tidak memiliki hasil yang sama dengan hasil penelitian di atas. Dari hasil perhitungan yang diperoleh nilai korelasi R square sebesar 0.046, hal ini berarti bahwa variabel independen yaitu kompensasi menjelaskan tentang variasi kinerja karyawan pada Perusahaan Warunk Bendito Manado sebesar 04,6\% yang berarti memiliki sifat korelasi yang sangat lemah.

\section{Kesimpulan}

Berdasarkan hasil penelitian tentang kompensasi terdapat bahwa lebih berpengaruh secara finansial terhadap kinerja karyawan dari pada secara non finansial karena gaji, insentif, tunjangan dan bonus sudah menjadi kebutuhan utama bagi karyawan;

Dari hasil penelitian yang didapat bahwa kompensasi memiliki pengaruh negatif terhadap kinerja karyawan sehingga karyawan tidak merasa puas dengan kompensasi yang diterima;

Berdasarkan hasil penelitian tentang kinerja karyawan bahwa karyawan memiliki sifat kinerja yang normal, meskipun demikian terdapat beberapa 
karyawan yang masih belum melakukan suatu tanggung jawab dengan sepenuhnya. Seperti datang bekerja tidak tepat waktu, jarang menggunakan seragam perusahaan dan cara melayani pelanggan yang masih belum maksimal;

Dari hasil yang didapat melalui observasi bahwa kinerja karyawan tidak sepenuhnya melakukan pekerjaan sesuai dengan standar dan terdapat pengeluhan dari beberapa karyawan tentang kompensasi yang belum sesuai dengan UMP (Upah Minimum Profinsi) yaitu Rp.3.050.000.

\section{Saran}

Berdasarkan hasil analisis, maka peneliti memberikan beberapa saran sebagai berikut:

Perusahaan Warunk Bendito Manado sebaiknya lebih memperhatikan pemberian kompensasi secara finansial yang diberikan kepada karyawan, agar kinerja karyawan lebih baik dan sesuai dengan apa yang diharapkan perusahaan; Pihak perusahaan sebaiknya memberikan kompensasi finansial seperti gaji sesuai dengan aturan pemerintah yaitu Upah Minimum Profinsi sebesar Rp.3.050.000 kemudian insentif, tunjang dan bonus yang sesuai dengan harapan karyawan agar tidak akan berdampak negatif pada kinerja karyawan dan karyawanakan melakukan kinerja yang lebih optimal dan merasa puas atas kompensasi yang diterima;
Pihak

perusahaan

harus memperhatikan lebih baik atas pekerjaan yang tidak sesuai dengan standar yang dilakukan oleh karyawan dalam bekerja, agar kinerja karyawan akan lebih meningkat;

Pihak perusahaan sebaiknya jangan memberikan gaji di bawa Upah Minimum Profinsi, karena akan dikenakan sanksi.

\section{Daftar Pustaka}

Dessler, Gary. 2015. Manajemen Sumber Daya Manusia. Ed. 14. Jakarta: Salmba Empat.

Edison, E., Anwar, Y. dan Komariyah, I. 2017. Manajemen Sumber Daya Manusia. Bandung, Alfabeta.

Jac Fitz-enz Barbara Davison. 2011. How to Measure Human Reseources Management. Kencana Prenada Media Group. Jakarta.

Kenelak, D., Pio, J. R. Dan Kaparang, S. G. 2016. Pengaruh Kompensasi Terhadap Kinerja Karyawan Pada Koperasi Serba Usaha Baliem Arabica Di Kabupaten Jayawijaya. Juenal Administrasi Bisnis. Vol 4, No. 4

Rumawas, W. 2015. The Impacts of Human Resource Development, Organi-zational Commitment, and Compensation on Employee Performance (A study conducted at Sulut Bank in North Sulawesi). International Journal of Humanities and Social Science Invention ISSN. www.ijhssi.org. Volume 4 Issue 8

Rumawas, W 2018. Manajemen Sumber Daya Manusia. Universitas Sam Ratulangi (Unsrat Press): Jln. Kampus Unsrat - Bahu Manado 
Sabuhari, R., dan Kamis, R. 2018. Pengaruh Budaya Organisasi, Karakteristik Kompetensi, Kepuasan Kerja Terhadap Kinerja Layanan Publik Pegawai Pada Kantor PT. Pos Indonesia (Persero) Di Kota Ternate. Jurnal Manajemen Bisnis Indonesia Vol 6, No 1 (2018)

Rumere, O. L., Pio, J. R., Tampi, E. R. J. 2016. Pengaruh Kompensasi Terhadap Kinerja Karyawan PT.Bank Tabungan Negara (Persero), Tbk. Kantor Cabang Manado. Jurnal Administrasi Bisnis. Vol 4, No 1

Pio, J. R. 2015. Kepemimpinan Spiritual Dimensi-Dimensi Sumber Daya Manusia. Yogyakarta: Puri Arsita A6 